\title{
ANALISIS PENGELOLAAN HUTAN KEMASYARAKATAN DI SEKITAR KAWASAN HUTAN LINDUNG REGISTER 30 KABUPATEN TANGGAMUS PROVINSI LAMPUNG TAHUN 2010
}

\author{
Feni Rosalia dan Yuni Ratnasari \\ Ilmu Pemerintahan Fakultas Ilmu Sosial dan Ilmu Politik Universitas Lampung \\ E-mail: feni-rosalia@yahoo.com / feni.rosalia@fisip.unila.a.c.id
}

\begin{abstract}
ABSTRAK. Hutan kemasyarakatan ( $\mathrm{Hkm})$ adalah hutan negara yang pemanfaatan utamanya ditujukan untuk memberdayakan masyarakat setempat. Kebijakan Hutan kemasyarakatan mengizinkan masyarakat untuk dapat mengelola sebagian dari sumberdaya hutan dengan rambu-rambu yang telah ditentukan Permintaan dari kelompok-kelompok petani hutan kemasyarakatan mengenai perizinan Hkm di sekitar kawasan hutan lindung register 30 Tanggamus sangat tinggi dan banyak tumbuh kelompok-kelompok baru yang merupakan kelompok-kelompok potensial menjadi kelompok pengelola Hkm yang bagus. Namun kenyataannya banyak kelompok tani yang belum memperoleh izin pengelolaan Hkm bahkan ada kelompok tani yang tidak mampu membuat draft/proposal izin pengelolaan Hkm, ketika akhir-akhir ini banyak terjadi alih fungsi hutan yang tidak sesuai peruntukan dan penggunaan lahannya.Tujuan penelitian adalah pertama, mengidentifikasi kendala apa saja yang dihadapi kelompok tani register 30 Kabupaten Tanggamus sehingga belum dapat membuat atau memperoleh izin Hutan Kemasyarakatan, dan kedua, mengetahui faktor-faktor pendukung untuk melakukan percepatan proses pengajuan perizinan Hkm di kawasan hutan register 30 Kabupaten Tanggamus. Melalui FGD dan wawancara dengan petani, aparat masyarakat, tokoh masyarakat, Watala dan Dinas Kehutanan diperoleh hasil bahwa kendala yang dihadapi kelompok tani di register 30 adalah adanya keterbatasan pengetahuan petani tentang proses/tatacara pengajuan izin pengelolaan Hkm, terbatasnya tenaga fasilitator, dan adanya "oknum" (elit desa, LSM dan bahkan aparat pemerintah) yang justru memanfaatkan kebijakan Hkm untuk mencari keuntungan sepihak. Faktor pendukung percepatan proses pengajuan perizinan Hkm di register 30 adalah melalui kegiatan pendampingan masyarakat/fasilitasi kepada kelompok tani dan pengemasan pesan dan pembuatan draft buku panduan $\mathrm{Hkm}$.
\end{abstract}

Kata kunci: Pengelolaan Hutan, Hutan Kemasyarakatan

\section{ANALYSIS OF FOREST MANAGEMENT COMMUNITY AROUND THE FOREST PROTECTED REGISTER 30 DISTRICT TANGGAMUS PROVINCE LAMPUNG IN 2010}

ABSTRACT. Community forestry (HKM) is the utilization of state forests is primarily intended to empower local communities. Policy Community forests to allow people to be able to manage a portion of forest resources with signs predetermined Demand from farmers groups of community forest about licensing HKM around the protected forest area registers 30 Tanggamus very high and a lot of growing new groups, which are groups -group potential into a good management group HKM. But in reality many groups of farmers who have not obtained permission community forest management there is even a group of farmers who are not able to draft / proposal management permit HKM, the purpose of the study is the first, identify what obstacles are faced by the farmer group registers 30 Tanggamus so it can not make or obtain permission Community Forest, and second, to know the supporting factors to accelerate the process of filing the licensing HKM in forest area registers 30 Tanggamus. Throughfocus group discussions andinterviews with farmers, officials public, communityleaders, Watalaand the Forest Serviceshowed that the constraintsfaced by farmers 'groups in theregister 30is thelackoffarmers' knowledgeabout theprocesses/procedurespermitapplication community forestmanagement, lack offacilitators, and the existence of "elements "(village elite, NGOs and even government officials) who actually utilize HKM policy to seek unilateral advantage. Factors supporting the acceleration of the licensing application process HKM in the register 30 is through community assistance/ facilitation to the farmer groups and packaging messages and drafting HKM guide books.

Key words: Forest Management, Forest Community

\section{PENDAHULUAN}

Hutan lindung register 30 Kabupaten Tanggamus dengan luas wilayah 16.060 hektar merupakan salah satu kawasan yang strategis sebagai penyangga kehidupan ekonomi, sosial dan ekologis bagi masyarakat . Pola alih fungsi hutan terjadi pada perubahan penggunaan lahan dalam kawasan, tingkat pertambahan penduduk, baik dari kelahiran maupun migrasi masuk, dan kemiskinan diyakini menjadi salah satu penyebab beralihnya fungsi lahan kawasan hutan tersebut. Salah satu cara mengatasi permasalahan tersebut adalah diterapkannya kebijakan Hutan kemasyarakatan (Hkm). Sistem pengelolaan hutan bertujuan untuk memberdayakan masyarakat (meningkatkan nilai ekonomi, nilai budaya, memberikan manfaat/benefit kepada masyarakat pengelola, dan masyarakat setempat), tanpa mengganggu fungsi pokoknya (meningkatkan fungsi hutan dan fungsi kawasan, pemanfaatan kawasan, pemanfaatan jasa lingkungan, pemanfaatan hasil hutan kayu, pemanfaatan hasil hutan bukan kayu dengan tetap menjaga fungsi kawasan hutan).

Bagi Provinsi Lampung, Hkm diharapkan dapat mencegah kerusakan hutan yang masih tersisa dan merehabilitasi hutan yang rusak dengan melibatkan sepenuhnya peran serta masyarakat di sekitar hutan. Hkm 
diharapkan pula dapat mengakomodasi dua kepentingan yang selama ini menjadi sumber konflik yaitu kepentingan pelestarian fungsi hutan dan kesejahteraan masyarakat setempat (Rahmat, 2002).

Hasil penelitian Tim studi Watala World Agroforestry Centre (2005) menunjukkan beberapa kendala yang dihadapi kelompok petani sekitar hutan di Provinsi Lampung. Kendala utama adalah kesulitan untuk mendapatkan izin pengelolaan hutan, sementara permintaan dari kelompok tani mengenai perizinan sangat tinggi, yaitu dari total 167 kelompok baru 15 kelompok yang mendapatkan izin Hkm, sebagaimana ditunjukkan pada tabel 1. Begitu juga dari kajian Cahyaningsih dkk (2006), permintaan dari kelompok-kelompok petani hutan kemasyarakatan mengenai perizinan $\mathrm{Hkm}$ di sekitar kawasan hutan lindung register 30 Tanggamus sangat tinggi namun banyak dari kelompok petani tersebut yang masih belum memperoleh izin pengelolaan hutan.

Walaupun Pemerintah beralasan mengeluarkan izin pengelolaan $\mathrm{Hkm}$ harus mempertimbangkan banyak hal karena memang di satu sisi tidak dapat menutup mata terhadap adanya kelompok tani yang sudah mendapatkan izin namun justru tidak bertanggung jawab akan hak dan kewajibannya sebagai kelompok tani dengan status penerima izin tersebut. Akibatnya hutan dieksploitasi semaksimal mungkin tanpa memperhatikan aspek ketahanan dan kelestariannya. Namun di sisi lain kelompok tani sebagai agen perubah yang akhir-akhir ini lebih dituntut kepada peran menjaga dan mengatur alih fungsi hutan perlu mendapat perhatian dan tentu saja sangat layak jika pengajuan permohonan izin pengelolaan $\mathrm{Hkm}$ dipandang sebagai sebuah prioritas yang harus dipertimbangkan baik oleh Dinas kehutanan, LSM maupun masyarakat pada umumnya.

Mengingat sulitnya petani membuat draft/ proposal izin pengelolan $\mathrm{Hkm}$ dan jikapun telah mengajukan namun izin pengelolaan Hkm tidak kunjung didapat, jelas berarti jika petani belum berada pada posisi sebagai pelaku utama pembangunan hutan, kondisi tersebut merupakan sebuah masalah yang membutuhkan jalan keluar. Hal penting pertama yang harus dilakukan adalah mengidentifikasi kendala apa saja yang dihadapi kelompok tani register 30 Kabupaten Tanggamus sehingga belum dapat membuat draf/proposal izin pengelolaan Hkm. Bahkan kalaupun sudah mengajukan izin mengapa tidak kunjung mendapat persetujuan dari Dinas Kehutanan. Setelah penyebab tersebut teridentifikasi penting dilakukan langkah berikutnya yaitu mencari faktor apa yang dapat dilaksanakan untuk mendukung percepatan izin Hkm bagi kelompok tani di register 30 Kabupaten Tanggamus tersebut.

\section{TUJUAN PENELITIAN}

1. Mengidentifikasi kendala apa saja yang dihadapi kelompok tani register 30 Kabupaten Tanggamus sehingga belum dapat membuat atau memperoleh izin Hutan Kemasyarakatan.

2. Mengetahui faktor-faktor pendukung untuk melakukan percepatan proses pengajuan perizinan Hkm di kawasan hutan register 30 Kabupaten Tanggamus sehingga tercipta kemandirian kelompok tani di kawasan hutan register 30 Kabupaten Tanggamus.

\section{METODE}

Penelitian lapangan dilakukan di register 30 Kabupaten Tanggamus. Pengumpulan data melalui observasi, wawancara, dan diskusi khusus untuk menyingkap pandangan yang tidak bersifat pribadi (melainkan yang bersifat kelompok) dilakukan dalam bentuk Focus Group Discussionn (FGD) (Walker dan Sinclair,1999). Pemilihan peserta FGD dan wawancara dilakukan secara purposive sebanyak 18 orang dengan kriteria mereka yang dianggap mengetahui dan memahami berbagai permasalahan petani dan Hkm, meliputi Dinas Kehutanan dan 6 kelompok tani

Tabel 1. Kelompok pengelola hutan di Provinsi Lampung

\begin{tabular}{|c|c|c|c|c|c|c|c|}
\hline \multirow{3}{*}{ No. } & \multirow{3}{*}{ Kabupaten } & \multicolumn{4}{|c|}{ Jumlah Kelompok } & \multirow{3}{*}{$\begin{array}{c}\begin{array}{c}\text { Jumlah } \\
\text { Anggota }\end{array} \\
\text { (KK) }\end{array}$} & \multirow{3}{*}{$\begin{array}{c}\begin{array}{c}\text { Luas } \\
\text { Garapan }\end{array} \\
\text { (Ha) }\end{array}$} \\
\hline & & \multirow[b]{2}{*}{$\mathrm{Hkm}$} & \multicolumn{2}{|c|}{ Sudah ada izin } & \multirow[b]{2}{*}{ Total } & & \\
\hline & & & IHHBK & $\begin{array}{l}\text { Dalam } \\
\text { Proses }\end{array}$ & & & \\
\hline 1. & Bandar Lampung & 1 & 0 & 1 & 2 & 520 & 530,90 \\
\hline 2. & Lampung Selatan & 2 & 3 & 1 & 6 & 1.169 & $1.859,00$ \\
\hline 3. & Tanggamus & 6 & 0 & 6 & 12 & 2.771 & $3.761,00$ \\
\hline 4. & Lampung Tengah & 0 & 104 & 0 & 104 & 4.407 & 5.319 .05 \\
\hline 5. & Lampung Timur & 0 & 0 & 4 & 4 & 147 & $*$ \\
\hline 6. & Lampung Utara & 1 & 3 & 3 & 7 & 1.161 & $1.877,25$ \\
\hline 7. & Lampung Barat & 5 & 0 & 9 & 14 & 2.269 & $4.975,95$ \\
\hline 8. & Way Kanan & 0 & & 18 & 18 & 2.458 & $4.916,00$ \\
\hline & TOTAL & 15 & 110 & 42 & 167 & 14.932 & $23.239,15$ \\
\hline
\end{tabular}

Sumber: Olah data hasil identifikasi kelompok per Kabupaten, 2005

Keterangan: *)= Luas tidak terindetifikasi 
(mewakili yang pernah mengajukan, akan mengajukan dan belum mengajukan izin Hkm). FGD juga dilakukan dengan melibatkan Watala dan formal leader (Kepala Desa/ termasuk aparat desa) sebanyak 6 orang, tokoh masyarakat 3 orang, dan kelompok-kelompok tani untuk mengetahui perspektif masyarakat terhadap implementasi kebijakan Hutan kemasyarakatan, permasalahan-permasalahan yang dihadapi dalam pelaksanaan Hkm, dan keterlibatan/ partisipasi masyarakat dalam kegiatan $\mathrm{Hkm}$, sebagai aktifitas awal untuk selanjutnya memperkenalkan media panduan Hkm sebagai alat bantu komunikasi penyuluhan dan sosialisasi tentang kebijakan Hkm dengan tujuan memberikan informasi/panduan tentang cara memperoleh Izin Usaha Pemanfaatan Hutan Kemasyarakatan yang pada gilirannya akan memandirikan masyarakat di kawasan hutan tersebut.

\section{HASIL DAN PEMBAHASAN}

\section{Kendala Kelompok Tani Dalam Pengajuan Draft/Proposal Izin Pengelolaan Hkm}

Dari hasil wawancara dan FGD kepada informan diperoleh hasil bahwa tingkat pengetahuan petani dalam pembuatan izin pengelolaan Hkm masih kurang. Keinginan petani untuk mendapatkan izin pengelolaan Hkm memang besar tetapi ternyata tidak didukung oleh kemampuan kognitif yang memadai. Petani memahami sebatas bahwa untuk memperoleh izin maka mereka harus mengajukan proposal, namun mereka tidak dapat membuat proposal, tidak memahami bagian atau isi proposal bahkan sebagian besar justru tidak memiliki kemampuan adminstratif yang memadai untuk membuat proposal tersebut.

Kendala lain adalah tidak tersedianya fasilitator lapang baik tenaga lapang dari dinas kehutanan maupun lembaga pendamping independen yang dapat membantu dan memfasilitasi pembuatan proposal pengajuan izin Hkm tersebut. Selama ini petugas dari Dinas kehutanan tidak ada yang ditempatkan khusus di lapangan / di lokasi / desa-desa di kawasan hutan. Demikian pula ketiadaan pihak lain yang secara independent dapat memberikan bantuan dan pengarahan cara membuat proposal yang baik dan benar. Akibat ketiadaan fasilitator, petani tidak memiliki tempat bertanya, mau bertanya pun selain karena lokasi kantor kehutanan yang cukup jauh juga karena akses ke sana membutuhkan biaya yang tidak sedikit. Lebih jauh adalah petani tetap membuat proposal semampu mereka saja tanpa mengetahui di mana letak kekurangan dari proposal yang mereka buat.

Faktor lain yang menjadi kendala yaitu belum ada publikasi peraturan yang berkaitan dengan penyelenggaraan Hkm apalagi di tingkat pekon (desa), serta kontrol/pengawasan oleh pihak kehutanan yang tidak partisipatif. Teknis pelaksanaan kebijakan Hkm belum banyak diketahui masyarakat. Masyarakat mengalami kesulitan mengajukan izin pengelolaan hutan, bahkan terindikasi adanya oknum-oknum (elit desa, LSM dan bahkan aparat pemerintah) justru memanfaatkan kebijakan Hkm untuk mencari keuntungan. Bahkan ada kelompok tani yang sudah mengeluarkan uang kepada oknum tertentu yang menjanjikan jika izin pengelolaan akan segera keluar, namun ditunggu-tunggu tidak juga mereka dapatkan lihat keputusan Menteri Kehutanan, 2007.

\section{Faktor-Faktor Pendukung Percepatan Pengajuan Perizinan Hkm}

Setelah melakukan wawancara dan FGD kepada narasumber diperoleh hasil bahwa sebagian besar petani tidak memiliki pemahaman yang baik dan benar akan draft/proposal pengajuan izin pengelolaan Hkm. Bertrand (1979) menyatakan perlunya strategi komunikasi yang tepat untuk mengatasi permasalahan kelompok petani.

Berdasarkan keluhan, masukan/saran, dan observasi di lapangan, maka para pihak menyepakati jika problema mereka akan ketidakmampuan membuat proposal hingga tidak kunjung keluarnya izin pengelolaan Hkm tersebut dapat diatasi dengan beberapa kegiatan, sbb:

a. Pendampingan Masyarakat/Fasilitasi

Pendekatan manajemen partisipatif memberikan kesempatan kepada masyarakat untuk terlibat dalam kegiatan penyusunan pelaksanaan programpengelolaan hutan kemasyarakatan, mulai dari pengurusan perizinan pengelolaan hutan kemasyarakatan, dan sebagainya. Kegiatan pendampingan masyarakat/ fasilitasi melalui Kelompok Pengelola Hutan Kemasyarakatan KPPHkm bertujuan meningkatkan kemampuan masyarakat setempat dalam mengelola organisasi kelompok, membimbing masyarakat mengajukan permohonan izin sesuai ketentuan yang berlaku, meningkatkan kemampuan masyarakat setempat dalam menyusun rencana kerja pemanfaatan hutan kemasyarakatan, meningkatkan kemampuan masyarakat setempat dalam melaksanakan budidaya hutan melalui pengembangan teknologi tepat guna dan peningkatan nilai tambah hasil hutan, meningkatkan kualitas sumberdaya manusia masyarakat setempat melalui pengembangan pengetahuan, kemampuan dan keterampilan, memberikan informasi pasar dan modal dalam meningkatkan daya saing dan akses masyarakat setempat terhadap pasar dan modal, dan meningkatkan kemampuan masyarakat setempat dalam mengembangkan usaha pemanfaatan hutan dan hasil hutan.

Jenis kegiatan pendampingan masyarakat/fasilitasi meliputi pengembangan kelembagaan kelompok masyarakat setempat, pengajuan permohonan izin, penyusunan rencana kerja hutan kemasyrakatan, teknologi budidaya hutan dan pengolahan hasil hutan, pendidikan dan latihan, akses terhadap pasar dan modal, dan pengembangan usaha.

Pada tahapan proses penyiapan dan pengajuan izin 
HKm, beberapa hal yang perlu diperhatikan oleh para kelompok tani HKm adalah sudah adanya kesiapan kelompok dan anggota kelompok untuk mengajukan izin kelola, siap dalam hal pembiayaan, telah menjalin komunikasi dan koordinasi dengan pihak pemerintah daerah, dalam hal ini Dinas Kehutanan Kabupaten, telah mempersiapkan dokumen-dokumen pendukung, seperti peta areal kelola kelompok, AD/ART kelompok, rencana kerja, daftar anggota, struktur kelembagaan kelompok, dan surat pengantar dari desa/kampung/pekon.

Melalui kegiatan pendampingan ini, masyarakat yang tergabung dalam KPPHKm memperoleh manfaat untuk menumbuhkan rasa memiliki dan bertanggungjawab terhadap pemeliharaan fungsifungsi hutan, meng-hindari penggarapan lahan hutan oleh pihak lain di luar anggota kelompok pengelola dan pelestari hutan, mendorong timbulnya hubungan yang serasi kearah mitra sejajar antara mitra usaha dengan KPPHKm, dan menumbuhkan pelaksanaan pembinaan petani hutan dan mempermudah penyebaran informasi, memungkinkan adanya hubungan kerjasama antara Kelompok Pengelola dan Pelestari Hutan kemasyarakatan (KPPHkm) dengan kelompok lainnya, dan meningkatkan pendapatan/ perekonomian anggota secara swadaya dan dalam kebersamaan. Kegiatan fasilitasi yang diberikan dari tahap permohonan IUPHKm (Izin Usaha Pemanfaatan Hutan Kemasyarakatan sampai pada IUPHHK-HKm (Izin Usaha Pemanfaatan Hasil Hutan Kayu-Hutan Kemasyarakatan).

b. Pengemasan pesan dan pembuatan draft buku panduan $\mathrm{Hkm}$

Meskipun peraturan perundang-undangan tentang Hkm telah dikeluarkan Pemerintah, namun penyelenggaraan Hkm masih lamban di daerah. Salah satu faktornya adalah terbatasnya memahami kebijakan dan kemampuan para penggiat kehutanan tentang Hkm. Padahal Pemerintah telah mengeluarkan berbagai peraturan perundangan tentang $\mathrm{Hkm}$ seperti Peraturan Menteri Kehutanan No. P.37/ Menhut-II/2007 tentang Hutan Kemasyarakatan jo Peraturan Menteri Kehutanan Republik Indonesia No.P.13/Menhut-II/2010 tentang Perubahan kedua atas Permenhut No. P.37. Media (buku) panduan dapat menyajikan tentang bagaimana memfasilitasi penyelenggaraan Hutan Kemasyarakatan dari tahap Izin Usaha Pemanfaatan Hutan Kemasayarakata (IUPHKm) serta Izin Usaha Pemanfaatan Hasil Hutan Kayu dalam Hutan Kemasyarakatan (IUPHHK$\mathrm{HKm})$.

Pada dua dekade terakhir ini di Indonesia dijumpai bahwa penggunaan media seperti buku panduan, komik maupun cergam, sangat efektif menyampaikan pesan-pesan pembangunan. Bahkan pada masyarakat yang sangat rendah tingkat literasinya (kemampuan membaca sekitar 15-18 kata per menit) di 2 desa di Lampung Barat (Cahyaningsih,dkk 2005) menunjukkan peningkatan pengetahuan secara nyata tentang sosialisasi kebijakan hutan kemasyarakatan. Dengan menggunakan bahasa Indonesia yang sederhana dan mudah dipahami di 4 desa di Kabupaten Lampung Barat, efektifitas media ini bisa mencapai 75\% dalam menyampaikan pesan-pesan tentang kebijakan hutan kemasyarakatan.

Dari hasil penelitian Cahyaningsih dkk, (2005) maka beralasan untuk menggunakan media/ buku panduan Hkm bagi kelompok tani tentang kebijakan Hkm dan menjadi pedoman dalam menyusun proposal perizinan pengelolaan $\mathrm{Hkm}$ dengan demikian akan terbangun kemandirian dan mengurangi ketergantungan petani terhadap keberadaan fasilitator dan menempatkan petani pada posisi pelaku utama pembangunan hutan lestari melalui program hutan kemasyarakatan. Media ini dapat digunakan sebagai mekanisme untuk mewariskan pengetahuan lokal di kawasan hutan lindung register 30 Tanggamus khususnya.

Pemilihan media cetak buku panduan Hkm sebagai alat bantu rekayasa sosial ini didasarkan pada substansi atau obyek pesan yang akan dimuat yaitu mengembangkan dan memasyarakatkan media/alat bantu partisipatif sebagai alternatif percepatan proses pengajuan perizinan $\mathrm{Hkm}$ di Kabupaten Tanggamus, terutama di tingkat kelompok tani, berdasarkan kebutuhan setempat, membangun kemandirian dan kerjasama di tingkat kelompok tani, mengurangi ketergantungan petani terhadap keberadaan fasilitator, dan menempatkan petani pada posisi pelaku utama pembangunan hutan lestari melalui program Hkm. Pada dasarnya obyek yang akan dimuat dapat dikategorikan sebagai pelaksanaan kebijakan Hutan kemasyarakatan di sekitar kawasan hutan lindung register 30 Tanggamus.

Substansi pesan utama adalah nilai-nilai positif pengelolaan hutan kemasyarakatan di Kabupaten Tanggamus yang terkendala ketersediaan fasilitator lapang yang memfasilitasi tingginya permintaan perizinan $\mathrm{Hkm}$ di kawasan tersebut. Substansi pesan sebagai rekayasa sosial untuk membangun kemandirian di tingkat kelompok tani sebagai pelaku utama pembangunan hutan lestari melalui program Hutan Kemasyarakatan. Disamping itu substansi pesan juga dimaksudkan untuk mengukuhkan kearifan sosial yang dimiliki masyarakat setempat terhadap kelestarian hutan. Kecuali itu, substansi pesan juga untuk mengoreksi sikap negatif dari masyarakat dengan ancaman pidana sesuai dengan peraturan perundang-undangan yang berlaku. 


\section{SIMPULAN}

Tingginya permintaan izin pengelolaan $\mathrm{Hkm}$ di register 30 Kabupaten Tanggamus Provinsi Lampung tidak diikuti oleh pengetahuan petani dalam pembuatan draft/ proposal untuk pengajuan izin itu sendiri. Akibatnya banyak kelompok tani yang tidak dapat membuat proposal bahkan sekalipun proposal sudah diajukan tetapi izin pengelolaan tidak kunjung diperoleh. Kendala lain adalah adalah tidak tersedianya fasilitator lapang yang dapat membantu dan memfasilitasi pembuatan proposal pengajuan izin Hkm tersebut. Belum ada publikasi peraturan yang berkaitan dengan penyelenggaraan $\mathrm{Hkm}$, kontrol/pengawasan oleh pihak kehutanan yang tidak partisipatif, serta adanya oknum-oknum yang justru memanfaatkan kebijakan Hkm untuk mencari keuntungan merupakan kendala lain dalam pengajuan izin pengelolaan $\mathrm{Hkm}$. Upaya percepatan pengajuan izin pengelolaan Hkm dilakukan melalui pendampingan masyarakat/fasilitasi serta Pengemasan pesan dan pembuatan draft buku panduan Hkm.

\section{DAFTAR PUSTAKA}

Bertrand, J.T. 1978. Communication Pretesting. Communication Laboratory, Community and Family Study Center, The University of Chicago, Chicago.

Cahyaningsih, 2005. Kebijakan Hutan Kemasyarakatan Di Lampung Barat. Hasil Penelitian kerjasama Dinas Kehutanan dan PSDA Kabupaten Lampung Barat-World Agroforestry CenterAsia Tenggara

Depertemen Kehutanan 2007. Surat Keputusan Menteri Kehutanan Nomor: P.37/Menhut-II/2007), tentang Hutan Kemasyarakatan

Rahmat, S. 2005. Peluang dan Tantangan Pengelolaan Hutan Kemasyarakatan di Provinsi Lampung. Hasil Penelitian,Buletin Kampung. Watala, Lampung.

Walker, D.H.,B. Tapa, dan F.L. Sinclair. 1995. Incorporation of Indigeneous Knowledge and Prespectives in Agroforestry Development. Part One: Review and Their Application. Agroforestry System, 30:235:248 